\title{
THE MANAGEMENT OF CHRONIC ILLNESS
}




\section{To Charles}




\title{
THE MANAGEMENT OF CHRONIC ILLNESS
}

\section{Patient and Doctor Perspectives on Parkinson's Disease}

\author{
RUTH PINDER
}

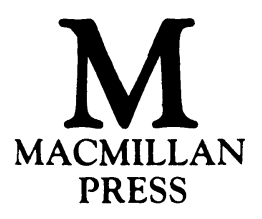




\section{(C) Ruth Pinder 1990}

All rights reserved. No reproduction, copy or transmission of this publication may be made without written permission.

No paragraph of this publication may be reproduced, copied or transmitted save with written permission or in accordance with the provisions of the Copyright, Designs and Patents Act 1988, or under the terms of any licence permitting limited copying issued by the Copyright Licensing Agency, 33-4 Alfred Place, London WC1E 7DP.

Any person who does any unauthorised act in relation to this publication may be liable to criminal prosecution and civil claims for damages.

First published 1990

Published by

THE MACMILLAN PRESS LTD

Houndmills, Basingstoke, Hampshire RG21 2XS

and London

Companies and representatives

throughout the world

Filmset by Wearside Tradespools,

Fulwell, Sunderland

British Library Cataloguing in Publication Data

Pinder, Ruth

The management of chronic illness.

1. Man. Parkinson's disease

I. Title

616.833

ISBN 978-0-333-49000-6

ISBN 978-1-349-21141-8 (eBook)

DOI 10.1007/978-1-349-21141-8 


\section{Contents}

Foreword by Christopher Ashton viii

Preface $\quad$ x

Chapter 1: INTRODUCTION 1

Uncertainty and the patient-doctor relationship 1

Background $\quad 4$

A note on the study $\quad 7$

P.D.: Facts and figures $\quad 8$

Chapter 2: EXPLAINING WHAT TO EXPECT: BELIEFS AND

ROUTINES 11

Introduction $\quad 11$

A spectrum of views $\quad 12$

Routines and innovations $\quad 19$

Summary and comment 23

Chapter 3: UNDERSTANDING THE IMPLICATIONS:

KNOWLEDGE AS A RESOURCE? 25

Introduction $\quad 25$

Information: friend or foe? $\quad 26$

The role of the GP 34

Summary and comment $\quad 38$

Chapter 4: THE DRUG REGIMEN: 'WE CAN TREAT IT' 41

Introduction 41

Rationale and side-effects $\quad 41$

Something tangible on offer 46

Medical management or shared management? 48

Summary and comment $\quad 52$ 
Chapter 5: THE HONEYMOON PERIOD-AND AFTER 54

Introduction $\quad 54$

Misunderstandings and understandings $\quad 55$

Being on tablets $\quad 57$

Room for manoeuvre or playing it by the book? 59

Patients' views of their GPs 63

Summary and comment $\quad 66$

Chapter 6: DETACHMENT OR EMPATHY? 68

Introduction $\quad 68$

Down to basics: progression, incurability and the

$\begin{array}{ll}\text { P.D. face' } & 69\end{array}$

Exploring fears and anxieties $\quad 71$

Listening, and just being there $\quad 75$

Summary and comment $\quad 81$

Chapter 7: CONTROLLING THE UNCONTROLLABLE:

MAKING SENSE OF LIVING WITH P.D. 83

Introduction $\quad 83$

Identity under threat $\quad 84$

In search of control $\quad 86$

Making a pact with P.D. $\quad 89$

How much can the GP offer? 91

Summary and comment 95

Chapter 8: CONCLUSIONS: PATIENT AND DOCTORMATCH AND MISMATCH 97

Introduction $\quad 97$

The study and its broader context 99

Casting a wider net $\quad 100$

Match and mismatch 103

Recommendations 109

Chapter 9: DOING RESEARCH: MORE THAN AN AFTERTHOUGHT $\quad 112$

Introduction $\quad 112$

Setting the scene $\quad 114$

Finding my patients and obtaining accounts $\quad 115$

GPs: An entry into a different world 118

And after ... $\quad 120$

Studying the powerless and the powerful $\quad 120$

$\begin{array}{ll}\text { Appendix 1: PATIENT PROFILE } & 127\end{array}$ 
Appendix 2: DOCTOR PROFILE

References

Index 


\section{Foreword}

It has often been stated that the care of a patient with a chronic illness should be based upon a close, effective relationship between patient and doctor. This relationship is of fundamental importance in determining how the patient experiences, manages and copes with his or her condition.

Using the model of Parkinson's Disease, Dr Pinder's research attempts to study and understand what it is that constitutes this fundamental, effective relationship. It was inspired by the lack of substantive emphasis and guidance on this aspect of care. Even in general practice, there has been, I believe, an emphasis on those aspects of the management of chronic illness which are most easily measured and have more to do with the structure than the content of care.

Dr Pinder has shown that understanding the doctor-patient relationship over the course of a progressive disabling illness such as Parkinson's Disease requires a departure from familiar models of medical research. To start with, I did not believe that an approach using such small numbers would have anything useful to contribute. It sounded anecdotal. In the light of her arguments, however, I have come to see things very differently. Not only is this a thoroughly systematic piece of research, fully as rigorous and demanding as the tradition in which I have been trained; it has yielded rich insights into the way patients and doctors manage a chronic illness from which the reader may gain considerable inspiration.

For the general practitioner the value of this work is twofold. First, in comparing and contrasting patients' views and feelings about various aspects of their illness, this research fosters a deeper understanding of the breadth of reaction to chronic illness. Second, all doctors will be able to identify with some of the attitudes expressed by the 18 general practitioners in this study. Reading the drafts of this book, I found that I often agreed with Dr Pinder's assessment of these attitudes, sometimes had to struggle to understand her critiques and occasionally protested loudly against them. The experience was always rewarding and the seeds of self-appraisal were planted.

Dr Pinder's achievement has been to identify from nine hundred pages 
of transcripted interviews certain attitudes, themes and concepts which further our understanding of the doctor-patient relationship over the course of a chronic illness.

I hope that these attitudes, themes and concepts are received by a wide audience, are understood, discussed, criticized and developed: they deserve to be.

July, 1989

Dr Christopher Ashton

Practising Family Practitioner, Sutton Coldfield 


\section{Preface}

'Why us? Why Parkinson's patients?' asked Mrs Unwin. It was a good question. The idea for this study arose from an interest in whether and, if so, to what extent, coming to terms with a debilitating illness was helped or hindered by patients' relationships with their GPs. That there might be two sides to this question was suggested by my husband's varied experiences with GPs at and after the onset of multiple sclerosis and, subsequently, by experience of others with M.S. At the time Parkinson's Disease seemed to have sufficient in common with M.S., while being interestingly different, to form the basis of a useful study.

I set out to study communication but soon found that I had to take a step back. It was necessary to consider first what both patient and doctor thought should and did happen between them. If, as is generally acknowledged, the presence of a caring, understanding and knowledgeable GP may make a great difference to the way patients experience and manage chronic illness, it is vitally important to understand what it is that makes for a satisfactory relationship, one that will be voluntarily sustained over time. It is this issue-communication in its widest sense-that the book seeks to address.

It reports on a research project conducted with a group of people with Parkinson's Disease (hereafter referred to as P.D. in the non-verbatim parts of the text) and a separate group of GPs, most of whom had had experience of P.D. patients. As the research shows, the experience and handling of the uncertainties inherent in chronic illness are the keys to the idea of satisfactory encounters between the two.

Doing the research for the book has left a lasting impression. I learned much from the patients who talked with me. I both knew, and in many ways did not know, what having P.D. was like. Pain and distress were evident and, trite as it may sound, so also was the sheer tenacity and courage patients showed in carrying on with life-some with, and others without, the support of their GP. It was, moreover, salutary to discover perfectly rational and intelligent patients who did not want to know 'the 
truth' about Parkinson's. My liberal ideas on the subject underwent a quiet sea-change.

I have explored the responses of patients and doctors to one particular condition, P.D. Yet it will be apparent that many of the thoughts and feelings expressed in this book could readily be applied to those with other chronic illnesses. But for the label, this could be patients speaking who have diabetes or rheumatoid arthritis. I believe GPs will also find similarities between their approach to P.D. patients and those suffering from the many other complaints with which they deal in their daily surgeries. This is a book as much about the universals as the particularities of people's responses to pain.

Despite initial apprehensions, interviewing GPs was a thoroughly enjoyable experience. Meeting them on a researcher-researched basis rather than in my normal capacity as a patient allowed me to see them as human beings, with the same strengths and frailties as others. This is not an anti-doctor book, and I hope that my comments will not be read in that light. In so far as I have been critical, this represents a plea for greater understanding in those areas where understanding may be most difficult to achieve. I hope that the findings will make a constructive contribution towards generating fresh thinking about general practice in the management of chronic illness.

Although I interviewed patients first, I have arranged the chapters so that doctors' accounts precede those of patients. The emphasis I wanted to achieve was: this is how GPs think about P.D. and communicating with their P.D. patients, but this is how patients see it. An appreciation of how both patient and doctor see the issues is the passport to a fuller understanding between them.

Chapter 1 introduces the concept of uncertainty, relates it to communication in the patient-doctor relationship and indicates where this study may extend our understanding. A brief note on the research design follows, and the chapter concludes with a short description of P.D., its incidence, prevalence and treatment.

The following chapters may most usefully be read in pairs, as a dialogue. Thus, Chapter 2 looks at the way GPs think about giving information to patients, while Chapter 3 traces patients' experience of coming to understand the illness and their own GPs' response to their struggles. Chapters 4 and 5 explore the two parties' views on handling information and sharing responsibility for the daily management of the drug treatment. Chapters 6 and 7 examine what the illness means to patients and how doctors and patients see the role of the GP in helping patients to come to terms with P.D. Chapter 8 draws these views and experiences together, looks at the broader implications for patient-doctor relationships in managing P.D. as well as other chronic illnesses, and suggests improvements in the education and training of GPs. The concluding chapter explores how the research was 
conducted and how my particular approach illuminates our understanding of the issues.

There are many people to thank for their support, particularly the Parkinson's Disease Society, which commissioned the research on which this book is based. The enthusiasm of the Society's Welfare Director, Mary Baker, often sustained me in writing this manuscript. I owe a special debt to my stalwart band of advisory readers. Dr Marie Oxtoby, Dr Christopher Ashton, Dr Roger Grimshaw and Judith Monks helped me to improve earlier drafts of this manuscript. John Morley OBE coaxed me to write tolerably crisp prose; and Dr Anna Wynne constantly encouraged me to scrutinize and broaden my ideas while alerting me to the nuances of a turn of phrase. Many of their suggestions have found their way into this text. Any errors or shortcomings are my responsibility alone. My thanks also go to my editor, David Grist; to Caroline Alexander for typing the text; and to Unwin Hyman for permission to reproduce passages from a chapter 'Striking balances: living with Parkinson's Disease' in Anderson and Bury's collection of studies on chronic illness. Above all, I want to thank the patients and GPs who generously gave their time and allowed me to share some of their thoughts and experiences. This book belongs to them. 